\title{
An Interesting Backbone Rearrangement and Novel Derivatives from the Biotransformation of Trachyloban-19-oic Acid by Rhizopus stolonifer
}

\author{
Eliane A. Silva ${ }^{a}$,Jacqueline A. Takahashi ${ }^{a *}$ and Alaíde B. Oliveira $^{b}$ \\ ${ }^{a}$ Departamento de Química, Instituto de Ciências Exatas, Universidade Federal de Minas Gerais, Av. Presidente \\ Antônio Carlos, 6627, 31270-901, Belo Horizonte - MG, Brazil \\ ${ }^{b}$ Departamento de Produtos Farmacêuticos, Faculdade de Farmácia, Universidade Federal de Minas Gerais, Av. \\ Olegário Maciel, 2360, 30180-112, Belo Horizonte - MG, Brazil
}

\begin{abstract}
O ácido traquilobânico (2) foi incubado com Rhizopus stolonifer, com o objetivo de se sintetizar novos derivados diterpênicos. Após vinte dias, quatro metabólitos foram extraídos, isolados e caracterizados, dos quais dois apresentaram-se hidroxilados nas posições $7 \beta$ (3) e 17 (5). Dois derivados rearranjados também foram isolados, os ácidos ent-16 $\beta$-hidroxi-caur-11-en-19-óico (4) e $9 \alpha, 16 \beta$-diidroxi-caur-11-en-19-óico (6). O rearranjo do esqueleto traquilobânico levando a derivados do tipo ent-16 $\beta$-hidroxi-caur-11-eno é condizente com a proposta biogenética que limita a ocorrência deste grupo raro de diterpenos caurânicos somente em plantas contendo representantes com esqueleto traquilobânico. Nenhum relato anterior sobre o isolamento dos diterpenos $\mathbf{5}$ e $\mathbf{6}$ foi encontrado na literatura.
\end{abstract}

\begin{abstract}
A biotransformation experiment of trachyloban-19-oic acid (2) was carried out with Rhizopus stolonifer. After twenty days of reaction, four metabolites were extracted, isolated and characterized: two trachylobane type compounds, the $7 \beta(3)$ and the 17 (5) hydroxyl derivatives, and two rearranged ent-kaur-11-en-19-oic acids, the $16 \beta(4)$ and the $9 \alpha, 16 \beta$ (6) hydroxylated compounds. Products 4 and $\mathbf{5}$ were isolated as their methyl esters $(\mathbf{4 a}$ and $\mathbf{5 a})$ after esterification of a mixture containing their corresponding acids. The rearrangement of a trachylobane diterpene leading to ent-16 $\beta$-hydroxykaur-11-ene derivatives gives support to the biogenetic proposal based on the occurrence of this rare group of kaurenes only in plants containing trachylobane representatives. By the best of our knowledge, this is the first report on the isolation of compounds 5 and $\mathbf{6}$.
\end{abstract}

Keywords: biotransformation, Rhizopus stolonifer, trachyloban-19-oic acid, rearrangement

\section{Introduction}

Microbial transformation of organic compounds is a valuable synthetic biocatalytic methodology to carry on regio- and stereoselective reactions. It is one of the few methodologies available for the functionalization of inactivated carbon atoms making possible to carry on reactions that have no equivalent in conventional chemistry. Steroid and terpenoid bioconversions, particularly hydroxylation, is an area in which biocatalysis is very useful. We have been exploring this methodology for structural modification of abundant kaurane and trachylobane diterpenoids, such as ent-kaur-16-en-19-oic ${ }^{1}$

*e-mail: jacfab@dedalus.lcc.ufmg.br
(1) and trachyloban-19-oic acids (2). These compounds and several relatives disclose a wide spectrum of biological activities such as anti-microbial, anti-tumor, trypanocidal, antifeeding and anti-HIV. ${ }^{2,3,4}$ Trachyloban-19-oic acid (2) is a tetracyclic diterpenoid, closely related to the ent-kaur16-ene series. Its natural occurrence in plants of the genus Xylopia (Annonaceae) ${ }^{5}$ and Helianthus (Compositae) ${ }^{4}$ is well reported. In this paper we report the hydroxylation of $\mathbf{2}$ by the biological reagent Rhizopus stolonifer aiming at the preparation of novel compounds for biological screening. Four biotransformated products were formed $(\mathbf{3}, \mathbf{4}, \mathbf{5}$ and $\mathbf{6})$, the two later being novel diterpene derivatives (5 and $\mathbf{6}$ ). Compounds $\mathbf{4}$ and 5 were isolated and characterized as their methyl esters (4a and $\mathbf{5 a})$ after esterification with diazomethane of a mixture eluted from the column chromatography of crude biotransformation extract. 


\section{Results and Discussion}

Trachylobanic acid (2) was isolated from seeds of Xylopia sericea and characterized by m.p., IR, ${ }^{1} \mathrm{H}$ NMR and ${ }^{13} \mathrm{C}$ NMR (Table 1) spectra. ${ }^{5}$ Its methyl ester (2a) was prepared, for comparison purposes, from ethereal diazomethane. ${ }^{13} \mathrm{C}$ NMR data for compound $2 \mathbf{2 a}$ are presented in Table 1. After twenty days of incubation of compound 2 with $R$. stolonifer, the aqueous extract was filtered, extracted and submitted to fractionation over silica gel column. Compounds $\mathbf{3}$ and $\mathbf{6}$ were isolated as pure compounds. Compounds $\mathbf{4}$ and $\mathbf{5}$ were recovered as a mixture and their separation was carried out by silica gel column chromatography after esterification of the mixture.

Table 1. ${ }^{13} \mathrm{C}$ NMR chemical shifts values ( $\delta$ in ppm) for compounds 2, 2a, 3, 4a, 5a and 6

\begin{tabular}{lcccccc}
\hline $\mathbf{C}$ & $\begin{array}{c}\mathbf{2} \\
\left(\mathrm{CDCl}_{3}\right)\end{array}$ & $\begin{array}{c}\mathbf{2 a} \\
\left(\mathrm{CDCl}_{3}\right)\end{array}$ & $\begin{array}{c}\mathbf{3} \\
\left(\mathrm{CDCl}_{3}\right)\end{array}$ & $\begin{array}{c}\mathbf{4 a} \\
\left(\mathrm{CDCl}_{3}\right)\end{array}$ & $\begin{array}{c}\mathbf{5 a} \\
\left(\mathrm{C}_{6} \mathrm{D}_{6}\right)\end{array}$ & $\begin{array}{c}\mathbf{6} \\
\left(\mathrm{C}_{6} \mathrm{D}_{6}\right)\end{array}$ \\
\hline 1 & 39.4 & 39.4 & 39.6 & 40.0 & 39.1 & 38.7 \\
2 & 18.7 & 18.7 & 19.1 & 19.5 & 18.8 & 20.0 \\
3 & 37.8 & 38.1 & 38.5 & 38.3 & 38.0 & 37.9 \\
4 & 43.7 & 43.7 & 43.5 & 43.6 & 44.0 & 44.2 \\
5 & 57.0 & 57.0 & 46.7 & 55.8 & 56.5 & 48.5 \\
6 & 21.7 & 21.8 & 30.4 & 22.4 & 22.0 & 23.0 \\
7 & 39.2 & 39.2 & 74.5 & 41.7 & 39.2 & 38.9 \\
8 & 40.7 & 40.7 & 45.9 & 44.0 & 40.9 & 50.5 \\
9 & 52.7 & 52.7 & 47.5 & 61.6 & 52.7 & 79.6 \\
10 & 38.9 & 38.6 & 39.9 & 38.9 & 39.7 & 44.3 \\
11 & 19.7 & 19.7 & 19.3 & 127.0 & 20.1 & 130.6 \\
12 & 20.6 & 20.6 & 20.4 & 133.7 & 22.0 & 133.3 \\
13 & 24.3 & 24.2 & 24.2 & 50.8 & 18.6 & 50.4 \\
14 & 33.1 & 33.1 & 32.6 & 34.8 & 32.8 & 33.0 \\
15 & 50.4 & 50.3 & 46.0 & 59.4 & 46.2 & 53.0 \\
16 & 22.4 & 22.4 & 23.1 & 82.9 & 30.6 & 81.0 \\
17 & 20.6 & 20.6 & 20.7 & 26.5 & 66.2 & 26.4 \\
18 & 28.9 & 28.7 & 28.8 & 28.7 & 28.3 & 29.7 \\
19 & 184.9 & 178.1 & 180.0 & 178.0 & 177.8 & 180.6 \\
20 & 12.4 & 12.3 & 12.5 & 15.7 & 12.3 & 18.5 \\
21 & - & 51.1 & - & 51.6 & 50.8 & - \\
\hline
\end{tabular}

Mass spectrum of product 3 showed the $\mathrm{M}^{+}$peak at $\mathrm{m} / \mathrm{z} 318$ in accordance with the molecular formula $\mathrm{C}_{20} \mathrm{H}_{30} \mathrm{O}_{3}$. A peak observed at $\mathrm{m} / \mathrm{z}, 300$ corresponding to $\mathrm{M}^{+}-\mathrm{H}_{2} \mathrm{O}$ was an indication that a hydroxylation of $\mathbf{2}$ had occurred. The ${ }^{1} \mathrm{H}$ NMR spectrum of $\boldsymbol{3}$ showed typical signals of cyclopropane hydrogens, $\mathrm{H}-12$ and $\mathrm{H}-13$ signals appearing as a double triplet at $\delta 0.65(J 7.8 \mathrm{~Hz})$ and a double doublet at $\delta 0.92(J 7.8$ and $3.1 \mathrm{~Hz})$, respectively. Two singlets were also observed at $\delta 1.21$ and 1.41 corresponding to six and three hydrogens, respectively, which were assigned to the hydrogens of C-17, C-20 and $\mathrm{C}-18$. The triplet at $\delta 3.86(\mathrm{~J} 5.5 \mathrm{~Hz})$ is characteristic of hydrogen in a hydroxylated carbon and it is consistent with the signal observed in the ${ }^{13} \mathrm{C}$ NMR spectrum at $\delta 74.5$. The assignments of the remaining signals were made by analysis of DEPT experiment and comparison with the ${ }^{13} \mathrm{C}$ NMR spectrum of trachyloban-19-oic acid (2). Disappearance of the signal corresponding to C-7 in the ${ }^{13} \mathrm{C}$ NMR spectrum, the downfield shift of C-6 and C-8 signals and the $\gamma$-gauche effect observed for C-5, C-9 and $\mathrm{C}-15$ indicated that the hydroxylation had occurred at C-7. This was confirmed by a ${ }^{1} \mathrm{H}-{ }^{1} \mathrm{H}$ COSY experiment that showed correlations of H-7 $(\delta 3.86)$ with the methylene hydrogens at C-6 ( $\delta 2.43$ and $\delta 2.45)$. HMQC experiment permitted the assignments of the most important chemical shifts for identification of $\mathbf{3}$ as, for example, the correlation of the signals of $\mathrm{H}-6, \mathrm{H}-14$ and $\mathrm{H}-15$. NOESY experiment allowed the definition of the $\beta$-configuration for the hydroxyl group at C-7 due to the correlations of $\mathrm{H}-7(\delta$ $3.86)$ with $\mathrm{H}-6(\delta 2.43$ and $\delta 2.45), \mathrm{H}-15 \alpha(\delta 1.74)$ and $\mathrm{H}-$ $14 \beta(\delta 1.30)$. The spectral data for 3 are in accordance with the literature. ${ }^{6}$

Compounds $\mathbf{4}$ and $\mathbf{5}$ were isolated as their methyl esters (4a and 5a) after esterification from diazomethane of a fraction obtained from a column chromatography of the crude biotransformated product. Comparison of the spectral data for $\mathbf{4 a}$ with those of methyl trachyloban-19oate (2a) showed only few similarities and, for explaining this difference, a rearrangement, leading to a molecule with a kaurene skeleton was proposed. The molecular formula $\mathrm{C}_{21} \mathrm{H}_{32} \mathrm{O}_{3}$ was deduced from the MS molecular ion $\left[\mathrm{M}^{+} 332\right]$ of 4a. Its ${ }^{1} \mathrm{H}$ NMR spectrum showed three methyl singlets at $\delta 0.90, \delta 1.19$ and $\delta 1.58$ as well as a double doublet at $\delta 5.58(\mathrm{~J} 9.8$ and $3.7 \mathrm{~Hz})$ and a triplet at $\delta 6.05(\mathrm{~J} 8.0 \mathrm{~Hz})$ corresponding to two olefin methinic hydrogens. The multiplicities observed for the olefinic signals indicate the occurrence of a dehydrogenation between C-11 and $\mathrm{C}-12$. A singlet at $\delta 3.61$ was assigned to the hydrogens of the methoxyl group and a double doublet at $\delta 2.52(J 12.4$ and $3.0 \mathrm{~Hz}$ ) corresponds to the signal of $\mathrm{H}-13$. The ${ }^{13} \mathrm{C}$ NMR spectrum for $\mathbf{4 a}$ showed signals of two olefinic carbons ( $\delta 127.0$ and $\delta 133.7)$ confirming that a dehydrogenation had occurred in the molecule of $\mathbf{2}$. No signal that could be assigned to hydrogen bounded to a hydroxylated carbon was found in the ${ }^{1} \mathrm{H}$ NMR spectrum, but the presence of a novel signal at $\delta 82.9$ was observed in the ${ }^{13} \mathrm{C}$ NMR spectrum and indicated that a quaternary carbon was linked to a hydroxyl group. ${ }^{7,8}$ The assignments of the remaining carbons resulted from the analysis of a DEPT experiment (Table 1). MS showed a peak at $m / z 314\left[\mathrm{M}^{+}\right.$$\mathrm{H}_{2} \mathrm{O}$ ] confirming the presence of a hydroxyl group. A typical peak of 16-hydroxy-kaurenes is the $\mathrm{m} / z, 274\left[\mathrm{M}^{+}\right.$ -58] that is formed from the molecular ion by cleavage between $\mathrm{C}-13$ and $\mathrm{C}-16$ with the migration of the 
hydroxylic hydrogen, followed by a rearrangement. The loss of the substituent at $\mathrm{C}-4\left(\mathrm{CO}_{2} \mathrm{CH}_{3}\right)$ led to the peak at $\mathrm{m} / z 215\left[\mathrm{M}^{+}-59\right]$. The cleavage of ring $\mathrm{B}$ with localization of the charge in ring $\mathrm{A}$ is characteristic of bicyclic diterpenes. It would lead to the peaks at $\mathrm{m} / \mathrm{z} 181$ and 121 , observed in the MS of $\mathbf{4 a}$, due to rearrangement. Cleavage of the bonds C-9 - C-10 and C-5 - C- 6 or C-6 - C-7 led to the peaks $m / z, 132$ and 146, respectively. ${ }^{9}$

${ }^{1} \mathrm{H}$ NMR spectrum of the third metabolite, the methyl ester 5 a showed signals at $\delta 0.98$ and $\delta 1.19$, characteristic of cyclopropane hydrogens in a trachylobane skeleton. Two singlets at $\delta 0.86$ and $\delta 1.16$ (H-18 and $\mathrm{H}-20$, respectively), and a singlet at $\delta 3.62$ (OMe) were also observed. A double doublet centered at $\delta 3.94$ ( $J 11.0$ and $8.0 \mathrm{~Hz}$ ) suggested the presence of a hydroxyl group in this molecule. This proposal was supported by the ${ }^{13} \mathrm{C}$ NMR spectrum and DEPT experiment that exhibited a signal at $\delta 66.2$ characteristic of a carbon of a primary alcohol. HMQC experiment showed correlation of the hydrogen signal at $\delta 3.62$ with the carbon signal at $\delta 50.8$, as observed for methyl trachyloban-19-oate (2a) and a downfield shift of the C-16 signal (from $\delta 22.4$ to $\delta 30.6$ ) (Table 1). NOESY experiment confirmed the localization of the hydroxyl group at $\mathrm{C}-17$ by showing correlation of $\mathrm{H}-17(\delta 3.94)$ with H-12 $(\delta 0.98), \mathrm{H}-13(\delta 1.19), \mathrm{H}-15 \alpha(\delta$ 1.58) and $\mathrm{H}-$
$15 \beta(\delta$ 1.86). Structure 5a was then proposed and it is in accordance with the peaks observed in MS. The peak at $m$ / z 313 was formed by loss of one molecule of water and a hydrogen atom. Peaks at $m / z 298\left[313-\mathrm{CH}_{3}\right]$ and $m / z 254$ $\left[313-\mathrm{CO}_{2} \mathrm{CH}_{3}\right]$ and $\mathrm{m} / \mathrm{z} 238\left[298-\mathrm{HCO}_{2} \mathrm{CH}_{3}\right]$ were also observed. Loss of $\mathrm{HCO}_{2} \mathrm{CH}_{3}$ gave a peak at $m / z 272$ that, after a rearrangement with loss of one molecule of water and a hydrogen atom, gave a peak at $m / z 253$. The later, by loss of a $\mathrm{CH}_{3}$ group led to the peak at $m / z 238$.

Analysis of the fourth metabolite (6) was based on IR, $\mathrm{MS},{ }^{1} \mathrm{H} \mathrm{NMR},{ }^{13} \mathrm{C}$ NMR data, DEPT, COSY and HMQC experiments. They indicated that $\mathbf{6}$ was structurally related to compound 4. Its IR spectrum showed typical absorptions for hydroxyl $\left(3400 \mathrm{~cm}^{-1}\right)$ and carboxyl $\left(1690 \mathrm{~cm}^{-1}\right)$ groups. The ${ }^{1} \mathrm{H}$ NMR spectrum presented singlets for three methyl groups at $\delta 1.39, \delta 1.48$ and $\delta 1.55$ that are characteristic of H-20, H-18 and H-17, respectively. The broad doublet at $\delta 5.72(J 9.9 \mathrm{~Hz})$ and the broadened double doublet at $\delta$ $6.04(J 9.7$ and $6.7 \mathrm{~Hz})$ are due to the olefinic hydrogens, $\mathrm{H}-11$ and $\mathrm{H}-12$, respectively, as confirmed by the correlations (COSY) observed among H-12 ( $\delta 6.04), \mathrm{H}-11$ $\left(\delta\right.$ 5.72) and $\mathrm{H}-13(\delta 2.50)$. The ${ }^{13} \mathrm{C}$ NMR spectrum and DEPT experiment indicated that modifications had occurred on B, C and D rings (Table 1) and that both hydroxylation and rearrangement had occurred in rings $\mathrm{C}$

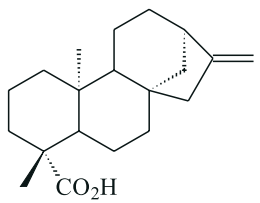

1

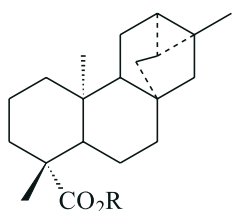

2: $\mathrm{R}=\mathrm{H}$

$\mathbf{2 a}: \mathrm{R}=\mathrm{CH}_{3}$

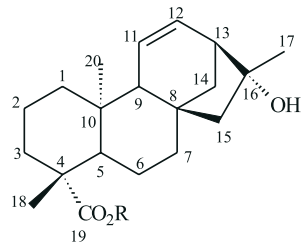

4: $\mathrm{R}=\mathrm{H}$

4a: $\mathrm{R}=\mathrm{CH}_{3}$

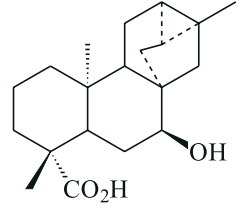

3

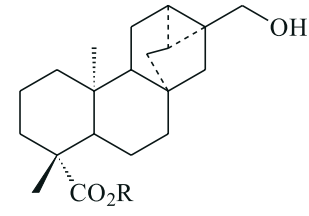

$5: \mathrm{R}=\mathrm{H}$

$\mathbf{5 a}: \mathrm{R}=\mathrm{CH}_{3}$

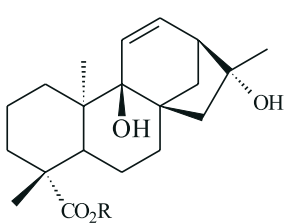

6: $\mathrm{R}=\mathrm{H}$

6a: $\mathrm{R}=\mathrm{CH}_{3}$ 
and D. The signals at $\delta 81.0$ and $\delta 79.6$ of the ${ }^{13} \mathrm{C}$ NMR spectrum are characteristic of $\mathrm{sp}^{3}$-oxygenated carbons and were not observed in the DEPT experiment, indicating that the hydroxyl groups were bound to quaternary carbons. The signal at $\delta 81.0$ was assigned to $\mathrm{C}-16$, as for compound 4a, while the signal at $\delta 79.6$ was attributed to C-9 since this signal has appeared in substitution to the corresponding one $(\delta 61.6)$ in the spectrum of compound 4a. The deshielding effect of the hydroxyl group reflected at C-8 and C-10 that, as expected, presented higher $\delta$ values in comparison with $\mathbf{4 a}$. The stereochemistry of the hydroxyl group at C-9 was defined as $\beta$ due to the $\gamma$-gauche effect observed for C-1, C-5 and C-7. MS supports the structure proposed for $\mathbf{6}$. Peak at $m / z 334\left(\mathbf{M}^{+}\right)$was compatible with the molecular formula $\mathrm{C}_{20} \mathrm{H}_{30} \mathrm{O}_{4}$. The formation of peaks at $\mathrm{m} / \mathrm{z} 316$ and 298, by successive loss of two molecules of water, confirmed the presence of two hydroxyl groups in the molecule. The peaks at $\mathrm{m} / \mathrm{z} 288$ and 270 were consecutively formed by loss of $\mathrm{HCO}_{2} \mathrm{H}$ and water. The peaks at $\mathrm{m} / \mathrm{z} 276$ and 230 were due to a rearrangement, loss of a 2-propenol molecule, followed by loss of $\mathrm{HCO}_{2} \mathrm{H}$. Methyl ester 6a has been reported by the literature, ${ }^{10}$ but no mention to the isolation of $\mathbf{6}$ was found.

From the biosynthetic point of view, it is interesting to note that ent-16 $\beta$-hydroxy-kaur-11-ene derivatives are rare in nature and have only been found in plants from which diterpenes with a trachylobane skeleton have also been isolated. ${ }^{7,8}$ Thus, compounds $\mathbf{4}$ and $\mathbf{6}$ have probably been formed by enzymatic abstraction of hydrogen at C-11, assisting the cleavage of the cyclopropane ring and forming a carbenium ion that, after neutralization with water, gave products 4 and 6.

\section{Conclusion}

Hydroxylation of inactivated carbons remains the most explored area in microbial transformation of organic compounds. This reaction makes possible the preparation of countless novel diterpenoids derivatives inaccessible by chemical means. Novel successful biotransformations, such as the trachylobanic acid (2) rearrangement we are describing bring about novel reactions that can be largely explored for a shorter synthesis of new chemical compounds of biological interest.

\section{Experimental}

\section{Experimental Procedures}

Melting points were determined on a Metler FPS apparatus and are uncorrected. IR spectra were recorded on a Shimadzu/IR-408 spectrophotometer. Crystalline samples were measured in $\mathrm{KBr}$ discs $(1.0 \mathrm{mg} \%)$. IR absorption bands were expressed in $\mathrm{cm}^{-1} .{ }^{1} \mathrm{H}$ NMR spectra were recorded in $\mathrm{CDCl}_{3}$ and $\mathrm{C}_{6} \mathrm{D}_{6}$ at $400 \mathrm{MHz}$ (Bruker Avance DPX 400), at room temperature, with TMS as internal standard. ${ }^{13} \mathrm{C}$ NMR spectra were determined at $100 \mathrm{MHz}$, in $\mathrm{CDCl}_{3}$ and $\mathrm{C}_{6} \mathrm{D}_{6}$ soln.. Assignments of chemical shifts were made with the aid of distortionless enhancement by polarization transfer (DEPT) using a flip angle of $135^{\circ}$ and bidimensional experiments (NOESY, COSY and HMQC). MS were determined on an Autospec model VG spectrometer. Silica used for flash chromatography was Merck 230-400 mesh.

\section{Isolation of 2}

Trachyloban-19-oic acid (2) was isolated from a hexane extract of Xylopia sericea seeds by silica gel column chromatography. ${ }^{5}$

\section{Microorganism}

A culture of Rhizopus stolonifer (CCT2002) was kindly donated from Coleção de Culturas Tropical, Fundação Tropical de Pesquisas e Tecnologia André Tosello, Campinas, SP, Brazil.

Media and culture conditions. PDA medium containing potato infusion (200 g), dextrose ( $20 \mathrm{~g})$, agar $(15 \mathrm{~g})$ at $\mathrm{pH} 6.5$ was used for storage of $R$. stolonifer. For the biotransformation experiments, a medium composed of dextrose ( $20 \mathrm{~g}$ ), peptone ( $5 \mathrm{~g}$ ), yeast extract $(3 \mathrm{~g}), \mathrm{KH}_{2} \mathrm{PO}_{4}$ $(5 \mathrm{~g})$ at $\mathrm{pH} 5.6$ in $\mathrm{H}_{2} \mathrm{O}(1 \mathrm{~L})$ was used. The microorganism was grown by a two-stage fermentation procedure. Erlenmeyer flasks $(500 \mathrm{~mL})$ containing $100 \mathrm{~mL}$ of medium were inoculated with a suspension of $R$. stolonifer. Incubations were maintained at $28^{\circ}$ in a rotary shaker, operating at $150 \mathrm{rpm}$ for $48 \mathrm{~h}$. An aliquot $(3.0 \mathrm{~mL})$ was used to inoculate similar flasks that were incubated under the same conditions. After $24 \mathrm{~h}$ of incubation, a solution of substrate $2(0.8 \mathrm{~g})$ was added in dimethylformamide (DMF) to a final concentration of $0.1 \mathrm{~g} \mathrm{~L}^{-1}$ and incubation was continued for twenty days.

Extraction, purification and analysis of microbial transformation products. After twenty days of incubation, the cultures were filtered off and the aqueous layer was extracted with EtOAc $(3 \times 200 \mathrm{~mL})$. The extracts were combined, dried over anhydrous sodium sulphate, filtered and the solvent was removed under reduced pressure, in a rotary evaporator, to give $1.2 \mathrm{~g}$ of residue. Flash column chromatography afforded $\mathbf{3}(19.8 \mathrm{mg}, 2.4 \%)$ and $\mathbf{5}$ (34.0 $\mathrm{mg}, 4.2 \%)$ by elution with $\mathrm{n}$-hexane/EtOAc $(8: 2)$. 
The residue obtained from some fractions $(15.0 \mathrm{mg})$ was esterified with diazomethane in ethyl ether and the reaction product was submitted to silica gel column chromatography leading to the separation of $\mathbf{4 a}(6.0 \mathrm{mg}, 0.74 \%)$ and $\mathbf{5 a}(5.0 \mathrm{mg}, 0.62 \%)$.

Trachyloban-19-oic acid (2): mp $160.2-162.3^{\circ} \mathrm{C}$ (lit. $^{2}$ 164-166 $\left.{ }^{\circ} \mathrm{C}\right)$; IR $v_{\max } \mathrm{cm}^{-1}: 2900,1700 \mathrm{~cm}^{-1} ;{ }^{1} \mathrm{H}$ NMR (400 $\left.\mathrm{MHz}, \mathrm{CDCl}_{3}\right) \delta 0.57(1 \mathrm{H}, \mathrm{m}, \mathrm{H}-12), 0.82(1 \mathrm{H}, \mathrm{m}, \mathrm{H}-12)$, $0.87,1.13$ and 1.21 (3H each, s, $\left.18,20,17-\mathrm{CH}_{3}\right){ }^{13} \mathrm{CNMR}$, see Table 1 .

7 $\beta$-Hydroxy-trachyloban-19-oic acid (3): $\mathrm{mp} 147.3-$ $148.9^{\circ} \mathrm{C}$ (lit. $\left.{ }^{10} 146-148{ }^{\circ} \mathrm{C}\right) ;{ }^{1} \mathrm{H}$ NMR $\left(400 \mathrm{MHz}, \mathrm{CDCl}_{3}\right) \delta$ $0.65(1 \mathrm{H}, \mathrm{dt}, J 7.8 \mathrm{~Hz}, \mathrm{H}-12), 0.92(1 \mathrm{H}, \mathrm{dd}, J 7.8,3.1 \mathrm{~Hz}, \mathrm{H}-$ 13), $1.21\left(6 \mathrm{H}, \mathrm{s}, 17\right.$ and $\left.20-\mathrm{CH}_{3}\right), 1.41\left(3 \mathrm{H}, \mathrm{s}, 18-\mathrm{CH}_{3}\right), 3.86$ $(1 \mathrm{H}, \mathrm{t}, J 5.5 \mathrm{~Hz}, \mathrm{H}-7) ;{ }^{13} \mathrm{C}$ NMR, see Table 1; EIMS $70 \mathrm{eV}, \mathrm{m} /$ $z$ (rel. int.) $318[\mathrm{M}]^{+}\left(\mathrm{C}_{20} \mathrm{H}_{29} \mathrm{O}_{3}\right)(8), 300\left[\mathrm{M}-\mathrm{H}_{2} \mathrm{O}\right]^{+}(100), 285$ $\left[300-\mathrm{CH}_{3}\right]^{+}(10), 272[\mathrm{M}-\mathrm{HCOOH}]^{+}(3), 255[300-\mathrm{COOH}]^{+}$ (10), $254\left[272-\mathrm{H}_{2} \mathrm{O}\right]^{+}(4), 239\left[254-\mathrm{H}_{2} \mathrm{O}\right]^{+}(6), 220$ (3), 185 (22), 157 (56), 146 (22), 133 (42), 118 (55), 105 (45).

Methyl ent-16ß-hydroxy-kaur-11-en-19-oate (4a): $\mathrm{mp}$ 132.2-135.6 ${ }^{\circ} \mathrm{C}$ (lit. $\left.{ }^{7} 131-133^{\circ} \mathrm{C}\right) ;{ }^{1} \mathrm{H}$ NMR $(400 \mathrm{MHz}$, $\left.\mathrm{CDCl}_{3}\right) \delta 0.90,1.19$ and 1.58 (3H each, s, 18, 20, 17- $\mathrm{CH}_{3}$ ), $2.52(1 \mathrm{H}, \mathrm{dd}, J 12.4$ and $3.0 \mathrm{~Hz}, \mathrm{H}-13), 3.61\left(3 \mathrm{H}, \mathrm{s}, \mathrm{OCH}_{3}\right)$, $5.58(1 \mathrm{H}, \mathrm{dd}, J 9.8$ and $3.7 \mathrm{~Hz}, \mathrm{H}-11), 6.05(1 \mathrm{H}, \mathrm{t}, J 8.0 \mathrm{~Hz}$, $\mathrm{H}-12) ;{ }^{13} \mathrm{CNMR}$, see Table 1; EIMS $70 \mathrm{eV}, \mathrm{m} / \mathrm{z}$ (rel. int.): $332[\mathrm{M}]^{+}\left(\mathrm{C}_{21} \mathrm{H}_{32} \mathrm{O}_{3}\right)(2), 314\left[\mathrm{M}-\mathrm{H}_{2} \mathrm{O}\right]^{+}(6), 299\left[314-\mathrm{CH}_{3}\right]^{+}$ (2), $274\left[\mathrm{M}-\mathrm{C}_{3} \mathrm{H}_{6} \mathrm{O}\right]^{+}(100), 257$ (5), 242 (7), 215 [274$\left.\mathrm{COOCH}_{3}\right]^{+}(11), 199$ (6), 173 (2) 145 (11), 121 (24), 106 (35), 91 (39).

Methyl 17-hydroxy-trachyloban-19-oate (5a): ${ }^{1} \mathrm{H}$ NMR $\left(400 \mathrm{MHz}, \mathrm{C}_{6} \mathrm{D}_{6}\right.$ ) $\delta 0.86$ and 1.16 (3H each, s, 18 and 20$\left.\mathrm{CH}_{3}\right), 0.98(1 \mathrm{H}, \mathrm{m}, \mathrm{H}-12), 1.19(1 \mathrm{H}, \mathrm{m}, \mathrm{H}-13), 3.62(3 \mathrm{H}, \mathrm{s}$, $\left.\mathrm{OCH}_{3}\right), 3.94(2 \mathrm{H}, \mathrm{dd}, J 11.0$ and $8.0 \mathrm{~Hz}, \mathrm{H}-17) ;{ }^{13} \mathrm{C} \mathrm{NMR}$, see Table 1; EIMS 70 eV, $m / z$ (rel. int.): 330 (8), 313 [330$\left.\mathrm{H}_{2} \mathrm{O}-\mathrm{H}\right]^{+}(36), 298$ [313- $\left.\mathrm{COOCH}_{3}\right]^{+}(26), 238$ (12), 212 (8), 198 (11), 185 (13), 159 (23), 147 (25), 121 (64), 105 (55).

Ent-9 $\alpha, 16 \beta$-dihydroxy-kaur-11-en-19-oic acid (6): $\mathrm{mp}$ 213.5 - 214. $3^{\circ} \mathrm{C}$; IR $v_{\max } / \mathrm{cm}^{-1} 3400,1900,1700 ;{ }^{1} \mathrm{H}$ NMR $\left(400 \mathrm{MHz}, \mathrm{C}_{6} \mathrm{D}_{6}\right) \delta 1.39,1.48$ and 1.55 (3H each, s, 20, 18,
17- $\left.\mathrm{CH}_{3}\right), 5.72(1 \mathrm{H}, \mathrm{d}, J 9.9 \mathrm{~Hz}, \mathrm{H}-11), 6.04(1 \mathrm{H}, \mathrm{dd}, J 9.7$ and $6.7 \mathrm{~Hz}, \mathrm{H}-12) ;{ }^{13} \mathrm{C}$ NMR, see Table 1; EIMS $70 \mathrm{eV}, \mathrm{m} / \mathrm{z}$ (rel. int.) $334[\mathrm{M}]^{+}\left(\mathrm{C}_{20} \mathrm{H}_{31} \mathrm{O}_{4}\right)(6), 316\left[\mathrm{M}-\mathrm{H}_{2} \mathrm{O}\right]^{+}(36), 298$ $\left[316-\mathrm{H}_{2} \mathrm{O}\right]^{+}(20), 288[\mathrm{M}-\mathrm{HCOOH}]^{+}(3), 276\left[\mathrm{M}-\mathrm{C}_{3} \mathrm{H}_{6} \mathrm{O}\right]^{+}$ (16), $270\left[288-\mathrm{H}_{2} \mathrm{O}\right]^{+}(27), 258\left[276-\mathrm{H}_{2} \mathrm{O}\right]^{+}(43), 243$ [258$\left.\mathrm{CH}_{3}\right]^{+}(100), 230[276-\mathrm{HCOOH}]^{+}(20), 213[258-\mathrm{COOH}]^{+}$ (17), $197[243-\mathrm{HCOOH}]^{+}(70)$.

\section{Acknowledgements}

The authors are grateful to the Fundação André Tosello, Brazil for the strain of $R$. stolonifer and to CNPq and FAPEMIG (Brazil) for financial support.

\section{References}

1. Silva, E.A.; Takahashi, J.A.; Boaventura, M.A.D.; Oliveira, A.B.; Phytochemistry 1999, 52, 397.

2. Mistcher, L. A; Rao, G. S. R.; Veysoglu, T.; Drake, S.; Haas, T.; J. Nat. Prod. 1983, 46, 745.

3. Ghisalberti, E.L.; Fitoterapia 1997, LXVIII, 303.

4. Fraga, B. M.; Phytochemical Analysis 1994, 5, 49.

5. Takahashi, J.A.; Vieira, H.S., Boaventura, M.A.D., Hanson, J.R., Hitchcock, P.B., Oliveira, A.B.; Quím. Nova 2001, 24, 616.

6. Hasan, C. M.; Healey, T. M.; Waterman, P. G.; Phytochemistry 1982, 21, 177.

7. Ohno, N.; Gershenzon, J.; Neuman, P.; Marby, T. J.; Phytochemistry 1981, 20, 2393.

8. Herz, W.; Govindan, S.V.; Watanabe, K.; Phytochemistry 1982 , $21,946$.

9. Kalinovsky, A. I.; Sebryakov, E. P.; Zolotarev, B. M.; Simolin, A. V.; Kucherov, V. F.; Chizhov, O. S.; Org. Mass Spectrom. 1970, 3, 1393.

10. Fraga, B.M.; Hernandez, M.G.; Fernandez, C.; Artega, J.M.; Phytochemistry 1987, 26, 775.

Received: July 19, 2001 Published on the web: December 14, 2001 